AND -..... (in press) Apomixis in Bothriochloa, Dichanthium, and Capillipedium. Phytomorphology.

Garber, E. D. 1944. A cytological study of the genus Sorghum: subsections Para-Sorghum and Eu-Sorghum. Amer. Naturalist 78: 89-94.

1950. Cytotaxonomic studies in the genus Sorghum. Univ. California Publ. Bot. 23: 283-362.

Golld, F. W. 1953. A cytotaxonomic study of the genus Andropogon. Amer. Jour. Bot. 40: 297-306.

- 1956. Chromosome counts and cytotaxonomic notes on grasses of the tribe Andropogoneae. Amer. Jour. Bot. 43: 395-404.
Hubbakd, J. 1950. A study of Andropogon ischaemum L. (Masters thesis.) A. \& M. College of Texas.

Krishnaswamy, N. 1941. Untersuchungen zur Cytologie und Systematik der Gramineen. Bot Centralbl. 60: $1-56$.

Kuwada, Y. 1919. On the number of chromosomes in maize. Jour. Col. Sci. Imp. Univ. Tokyo. 39: 1-148.

Merra, K. L. 1955. Chromosome numbers in the tribe Andropogoneae, Gramineae. Indian Jour. Gen. and Plant Br. 15: 144.

Stebbins, G. L. 1950. Variation and evolution in plants. New York.

\title{
AN UNUSUAL NEW CHEILANTHOID FERN FROM CALIFORNIA ${ }^{3}$
}

\author{
W. H. Wagner, Jr. and Elizabeth F. Gilbert ${ }^{2}$
}

Recent stldents of phylogeny in Filicineae have been interested in two general problems especially - the value of the conventional characters used in taxonomy, and the effects of hybridization in producing species. The traditional "key" character of the sorus does not always confirm relationships. Wholly unrelated plants may have similar sori; and conversely, ferns demonstrated by their constellation of other characters to have near affinity may differ from one another in such extremes as marginal vs. dorsal sori, or coenosori vs. discrete sori. The other general problem concerns particularly the numerous intermediate taxa which have been described among ferns. Cytological and experimental work now suggests that in the future most if not all of these intermediate ferns will be shown to be species hybrids. These two conclusions bear on the new plant to be described here.

The description of a presumably new species of fern from the United States is a rare event in the present day. The fern discussed here also possesses unusual taxonomic significance in that it seems to be an exact intermediate between two species often treated as belonging to separate genera. The sori of the generically separated ferns are sharply dissimilar. Copeland (1947) placed them, both familiar cheilanthoid ferns of the west coast, in distinct genera of his Pteridaceae. One of them is the "Oregon cliffbrake," Onychium densum Brackenridge, which has been variously treated by other authors as a Pellaea (for example, Jepson, 1923), a Cheilanthes (as C. siliquosa Maxon, 1918; and Fernald, 1950), and a Cryptogramma (Diels, 1899). Fernald (1950) wrote that "by its dimorphic fronds and aspect [it could be] about as well placed in Cryptogramma." The other of the spec es

${ }^{1}$ Received for publication April 24, 1957.

We are indebted to the directors of the University of California and University of Michigan herbaria for the loan of herbarium specimens. We wish also to thank Mr. Robert S. Whitmire for making a spore germination test for us, and Mr. Conrad V. Morton for his help in various ways. involved, the "California lace fern," interpreted by Copeland as Aspidotis californica Nuttall, has had almost as diverse a generic career: it was put in Hypolepis by Hooker (185I) and more recently in Cheilanthes by most authors (Jepson, 1923). Although the taxonomists have disagreed on exactly what the generic assignment of these two ferns should be, many of them do agree that, whatever the case, they should be kept in separate genera. Only Maxon (1918) seems to have been entirely convinced that the two plants are congeneric.

In the comparative study of the new, intermediate species to be described here, it was discovered that there are but few good characters that really separate "Onychium densum" and "Aspidotis californica," and that at least one of the alleged differences is actually invalid. Accordingly, they will both be treated in this paper as belonging to the same genus, Cheilanthes. The intermediate fern is known at present only from a narrow range, in San Luis Obispo, San Benito, and Marin counties, the few collections scattered over an area of some 180 miles along the coast of California, at distances inland from 10 to 60 miles. The late Mrs. Carlotta C. Hall, a student of western ferns over many years, was the first to recognize the intermediate plant as possibly distinct. The purpose of this report is to describe the new species, to compare it with its two immediate relatives, and to discuss its possible evolutionary significance.

CheILAnThes carlotta-halliae ${ }^{3}$ Wagner and Gilbert, sp. nov. A small tufted fern of dry, rockysoil habitats, with 5-10 photosynthetic leaves, 6-27 $\mathrm{cm}$. tall, and numerous persistent dark-pigmented old petioles. Stem creeping, dying off posteriorly and leaving a rhizome $1-5 \mathrm{~cm}$. long and $0.2-0.5$ mm. thick, completely clothed with old petiole-

${ }^{3} \mathrm{~A}$ C. californica et C. siliquosa stipitibus atrocastaneis $11.5(4.0-19.0) \mathrm{cm}$. longis, laminis triangularibus 4-pinnatis, $4.5(2.8-8.2) \mathrm{cm}$. longis, $2.7(1.4-5.5) \mathrm{cm}$. latis, pinnis infimis 3 (1-5) -jugis basaliter atrocastaneo-tinctis, coenosoris marginalibus valde interruptis vel soris discretis varie elongatis, sporis $46.7(23-61) \mu$ diam, differt. 
bases and roots that increase its apparent diameter to $1-2 \mathrm{~cm}$.; roots abundant, wiry, $0.4 \mathrm{~mm}$. in diameter, and extending 5-15 cm. or more in soil; paleae covering the sides of the rhizome, shoot apex, and petiole bases, linear-attenuate, $0.1-0.3$ $\mathrm{mm}$. broad at base, $1.5-2.0 \mathrm{~mm}$. long, shiny, with an opaque black central strip and translucent brown margins; leaves wiry and coriaceous, 15 (6-27) cm.tall; petiole atrocastaneous, lustrous, 11 (4-19) $\mathrm{cm}$. long, 0.7-1.0 mm. thick, devoid of scales in the mature state except at base; leafblade deltoid, four times divided, 4.5 (2.8-8.2) $\mathrm{cm}$. long, $2.7(1.4-5.5) \mathrm{cm}$. broad, the basal pinna pairs triangular, $2.3(1.5-3.0) \mathrm{cm}$. long, 1.5 (1.02.0) broad at base; midrib atrocastaneous and lustrous (like petiole) except for the green apical third or fourth; pinna axes mostly pale green, but atrocastaneous basally on the abaxial surface of the lower $3(1-5)$ pinna pairs; ultimate segments linear-acuminate to lanceolate-acuminate, 2-8 $\mathrm{mm}$. long, $1.0(0.8-1.5) \mathrm{mm}$. broad, the margins more or less shallowly dentate; sorus a strongly interrupted marginal coenosorus or divided completely into discrete sori of various lengths; indusium varying from an irregularly lobed and cut coenoindusium to an irregular series of discrete indusia, the indusial flap $0.3-0.5 \mathrm{~mm}$. broad; spores smooth, spherical, 46.7 (23-61) microns in diameter, pale-brown, with darker triradiate lines extending nearly one-fourth of the circumference.

TYPF SPECIMEN.-Locally abundant in dry rocky soil below picnic ground, Bootjack Camp, Mt. Tamalpais, Marin Co., California, W. H. Wagner 4604, February 10, 1948 (MICH).

Collections examined.-California: Marin County: Tiburon Hills along gully, Feb. 23, 1930, Alice Eastwood (UC) ; Bare hillsides, Tiburon, Katherine Brandegee, 1907 (UC); "Rhizopogon growing among roots," Mt. Tamalpais, H. E. Parks 3086 (UC) ; Bootjack Camp, Mt. Tamalpais, February, 1948, W. H. Wagner 4604 (UC, MICH-Type, US, GH). San Benito Co.: Rock outcrops, alt. $4500 \mathrm{ft}$., just over ridge from New Idria Mine, Clear Creek, Gregory Lyon 1274, June 28, 1938 (UC). San Luis Obispo Co.: Upper Chorro Creek, dry stream among rocks, I. I. Condit, April 16, 1910 (UC).

The nearest relatives of the new fern are obviously the two species which are treated here as species of Cheilanthes in the absence of a clearer definition of genera in this circle of affinity. Cheilanthes siliquosa is a well-known plant of wide range in North America, extending from Quebec and Ontario west to southern British Columbia and south to Wyoming, Utah, and southern California. Its habitat is most commonly on serpentine or limestone rocks in dry and more or less barren country. The leaf-blades of $C$. siliquosa are usually only 2 to 3 times divided at most, and its ultimate divisions are linear. It has a long coenosorus with a prac- tically straight, finely toothed flap (fig, 1, A, and 2,D). By Copeland (1947) the long sorus was considered to be subtended by a connecting vein along the laminar margin. The other species, $C$. californica has a much narrower range, and is known at present only from the state of California, where it is probably an endemic. The habitat of this fern is also on rocks or rocky ground, but it does not seem to be so specifically limited to serpentine or limestone. The leaf-blades are very finely divided, usually 4-5-times pinnate. The ultimate divisions tend to be broad, either lanceolate or triangular, and the sori are always short and entirely discrete structures, less than $1 \mathrm{~mm}$. in breadth and well separated from adjacent sori on the same segment margin (fig. $1, \mathrm{C} ; 2, \mathrm{~F}$ ). No commissural vein has been reported. In discussing the relationships of $C$. carlotta-halliae, each of its distinctive features will be considered in terms of the corresponding characters of these two other species.

The comparative data of leaf and soral characteristics given below are based on 100 dried plants of C. siliquosa, 71 of C. carlotta-halliae, and 50 of $C$. californica. Although use of herbarium specimens is not ideal, the collections had probably been accorded much the same treatment, making reasonably valid comparisons possible. A total of 11 characters of the three taxa involved were measured in the expectation of establishing differences. Of these, however, only seven yielded quantitative results of recognizable comparative value.

The ratio of blade length to stipe length is differ. ent among these plants: $C$. siliquosa has relatively the longest petioles, its stipe/blade ratio averaging 3.1 (1.1-8.1); in C. carlotta-halliae this value is 2.6 (1.5-4.9); and in C. californica, 2.1 (0.5-3.8). The atrocastaneous pigmentation of the midrib varies in the amount to which it extends to the pinna axes, and it was found that an average of 1.7 (1-4) of the lower pinna pairs of $C$. siliquosa are darkly pigmented basally; $3.0(1-5)$ in $C$. carlotta-halliae; and $4.0(1-7)$ in C. californica.

Shapes of the individual ultimate segments of these plants differ on the same leaf-blade because of the manner of cutting. In order to compare the segments of the three taxa, therefore, it was necessary to choose an arbitrary part of the blade upon which to make measurements. The median or abovemedian (if there were no precisely median segment) basiscopic segment of the basal pinnule of the lowest pinna was selected, and the ratio of length to width determined. In $C$. siliquosa this ratio proved to be the largest, $4.5(1.7-9.0)$, in C. carlotta-halliae it is intermediate, 3.6 (1.6-7.0), and in $C$. californica, the smallest, 2.5 (1.5-5.0). These values reflect the extreme segment shapes of narrowly linear in $C$. siliquosa and broader and more triangular in C. californica (fig. $1, A$ and $C$ ).

The most conspicuous differences among these 

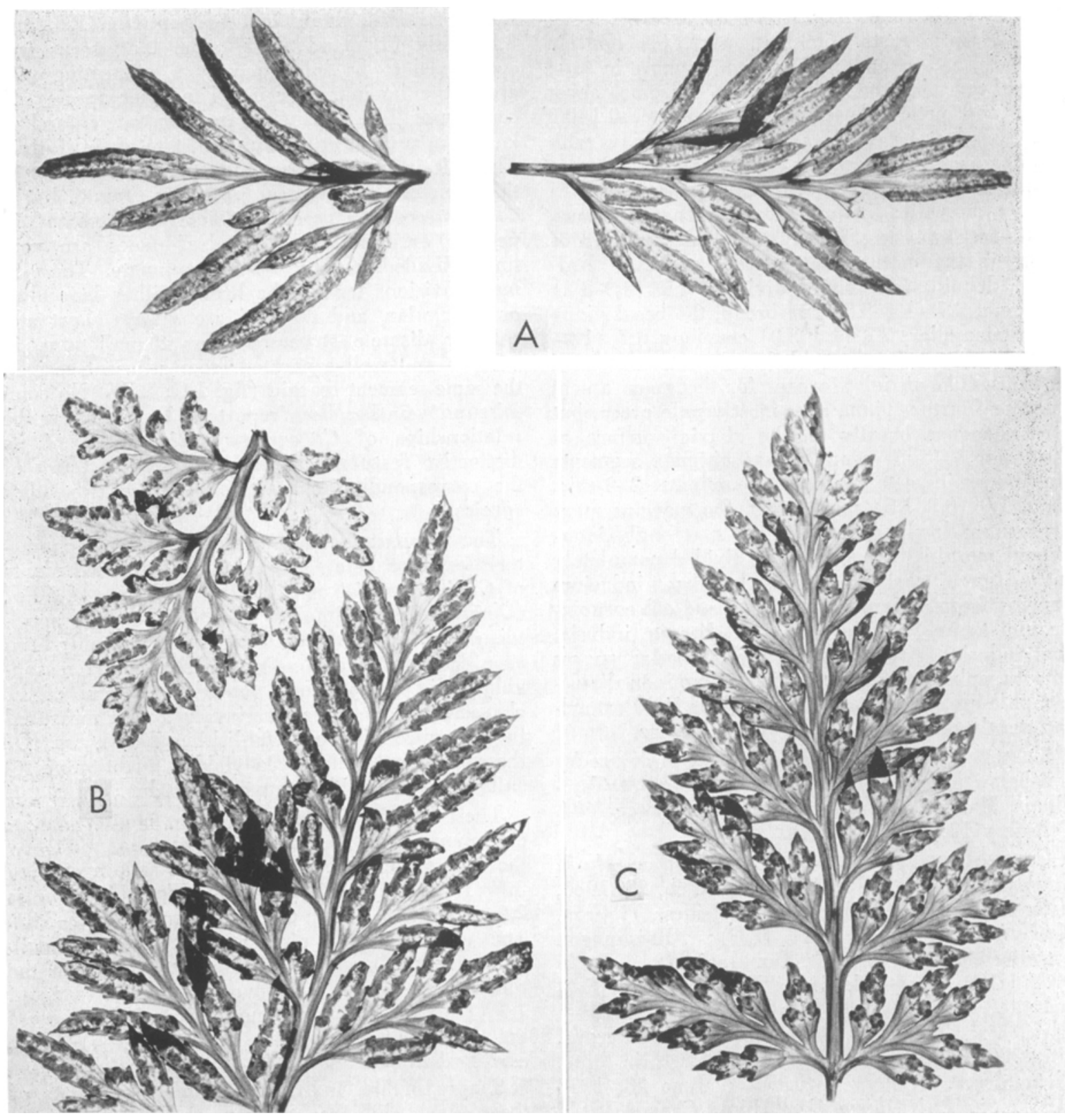

Fig. 1. Lateral pinnae (minus basal pinnules) cleared in sodium hydroxide and stained.-A. Cheilanthes siliquosa, Waldo, Oregon, Ownbey 1768 (MICH).-B. C. carlotta-halliae, Marin Co., Calif., Wagner 4604 (MICH), small segment juvenile-C. C. californica, Fall Brook, Calif., Marcus Jones (MICH).

taxa are involved in the structure of the sori (compared in fig. 2, D, E, F). The one extreme is provided by the continuous coenosorus of $C$. siliquosa and the other by the well separated and discrete sori of $C$. californica. The soriation of $C$. carlottahalliae is not only intermediate, but its sori are remarkably irregular in their development as well and this is the best character to identify the new species. One leaf segment may show a practically continuous coenosorus roughly like that of $C$. sili- quosa, and another one, next to it, may have discrete sori somewhat like those of $C$. californica. The differences may be seen on two sides of the same segment (fig. 2). In an attempt to state this difference quantitatively, the total of all the separate sori, regardless of length, was counted under a dissecting microscope on the basiscopic segments of the lowermost pinnule of the lowest pinna. Each distinct indusium which covered mature sporangia was considered to represent one sorus. In $C$. sili. 
TABLE 1. The major differentiating measurements of three Californian cheilanthoid ferns summarized

\begin{tabular}{lccc}
\hline \hline & & & \\
& C. siliquosa & C. carlotta-halliae & C. californica \\
Petiole length (cm.) & $10.8(3.8-23.0)$ & $11.5(4.0-20.0)$ & $11.2(3.5-22.0)$ \\
Blade length (cm.) & $3.5(1.7-7.9)$ & $4.5(2.4-8.2)$ & $5.4(2.3-9.7)$ \\
Petiole/blade length ratio & $3.1(1.1-8.1)$ & $2.6(1.5-4.9)$ & $2.1(0.5-3.8)$ \\
Blade width (cm.) & $2.2(1.0-4.2)$ & $2.7(1.4-5.5)$ & $4.4(1.4-8.8)$ \\
Number of pigmented pinna pairs & $1.7(1-4)$ & $3.0(1-5)$ & $4.0(1.5-5.0)$ \\
Length/width ratio median basiscopic segment of basal pinna & $4.5(1.7-9.0)$ & $3.6(1.6-7.0)$ & $2.5(1.5-5.0)$ \\
Number of sori on basiscopic segments of lowermost pinnule & $5.9(2-14)$ & $13.4(4-37)$ & $35.1(7-103)$ \\
Spore diameter $(\mu)$ & $40.7(37-52)$ & $46.7(24-61)$ & $38.5(33-47)$
\end{tabular}

quosa, the number was $5.9(2-14)$; in C. carlottahalliae, $13.4(4-37)$; and in $C$. californica, 35.1 (7-103). Copeland (1947, p. 47) keys out $C$. siliquosa (as Onychium densum) as having "veinlets free below the sorus but connected in them" in contrast to $C$. californica (as Aspidotis californica) with "veinlets everywhere free." One would expect from description, therefore, that the situation in $C$. siliquosa was analogous to that in the typical pteroid ferns, where the coenosori are provided with commissural veinlets subtending the marginal receptacle. However, we failed to find such a condition in $C$. siliquosa and accordingly consider this to be an untenable generic distinction. In fact, cleared and stained specimens show that the fertile veins of $C$. siliquosa (as shown in fig. 2,A), are essentially identical with those of $C$. californica.

The last significant difference among these plants is found in the spore size. All three have globose spores which are lightly pigmented. But 100 measurements of spores of each species show that those of $C$. siliquosa and $C$. californica are nearly similar to each other, $40.7(33-52) \mu$ in diameter in the former, and $38.5(33-47) \mu$ in the latter, but that those of $C$. carlotta-halliae are considerably larger, $46.7(24-61)$ p. A spore germination test for viability of $C$. carlotta-halliae was made on nutrient agar, and uniform and normal germination and gametophytic growth occurred.

Discussion.- It seems clear that the plant described as new here should be maintained as a distinct species. However, it is equally clear that Cheilanthes carlotta-halliae is a species intermediate between two others, $C$. siliquosa and $C$. californica. There are two problems involved: (1) Is C. carlotta-halliae a hybrid? (2) Are the characters of $C$. siliquosa and $C$. californica distinct enough to warrant their generic separation?

It seems probable that $C$. carlotta-halliae is the allopolyploid hybrid of the two other ferns. That it may be a polyploid is indicated by its spore size, which is definitely larger than either of its putative parents, a situation analogous to that in a number of suspected or proven allopolyploids in other ferns. That it may be a hybrid is suggested by several facts. The first is that $C$. carlotta-halliae is a rare plant, known only from a few counties of California. In the three counties where it does exist, it grows in the zone of overlap between the wide range of $C$. siliquosa and the west coast endemic range of $C$. californica. The second point is that the characters of $C$. carlotta-halliae are transitional between the parental species in question. These characters include the petiole/blade length ratio, blade segmentation, axis pigmentation, and soriation. A third reason for believing $C$. carlotta-halliae to be a hybrid is a peculiarity of the sori. It has been stressed that the sori of $C$. carlotta-halliae are intermediate between those of the supposed parents, but are, in addition, extremely irregular in form. In a number of ferns of proven or suspected hybrid origin, it has been observed that if the parents differ sharply in one or more characters, these characters will be irregularly and asymmetrically expressed in the hybrid taxon. This "irregularity phenomenon" is known in the over-all blade architecture of a hybrid $A d i$. antum (Wagner, 1956); in the blade segmentation of three hybrid species of Asplenium (Wagner, 1954); in the venation pattern of a hybrid Polystichum (Wagner and Hagenah, 1954); and in the bulblet structure of putative hybrids of Cystopteris (Wagner and Hagenah, 1956). It seems possible that such irregular morphological expressions may have considerable morphogenetic interest in future research on species characters.

Concerning the second problem, whether the presumed parents of $C$. carlotta-halliae are sufficiently distinct to be treated as genera, the mere fact that there does exist a plant such as the new one described here which "bridges the gap" morphologically between them, suggests that they should not be upheld in distinct genera. Furthermore, even without a clearly intermediate form, the number and character of the demonstrable differences between $C$. siliquosa and $C$. californica seem so trivial that generic separation would not be warranted. A difference between coenosori and discrete sori in this case does not seem to be taxonomically significant at the generic level. Maxon (1918) has already discussed his view of the relationships between these two plants, and entirely without knowledge of $C$. carlotta-halliae, concluded that "actually $[C$. siliquosa $]$ is of very close relationship to C. californica, despite D. C. Eaton's 

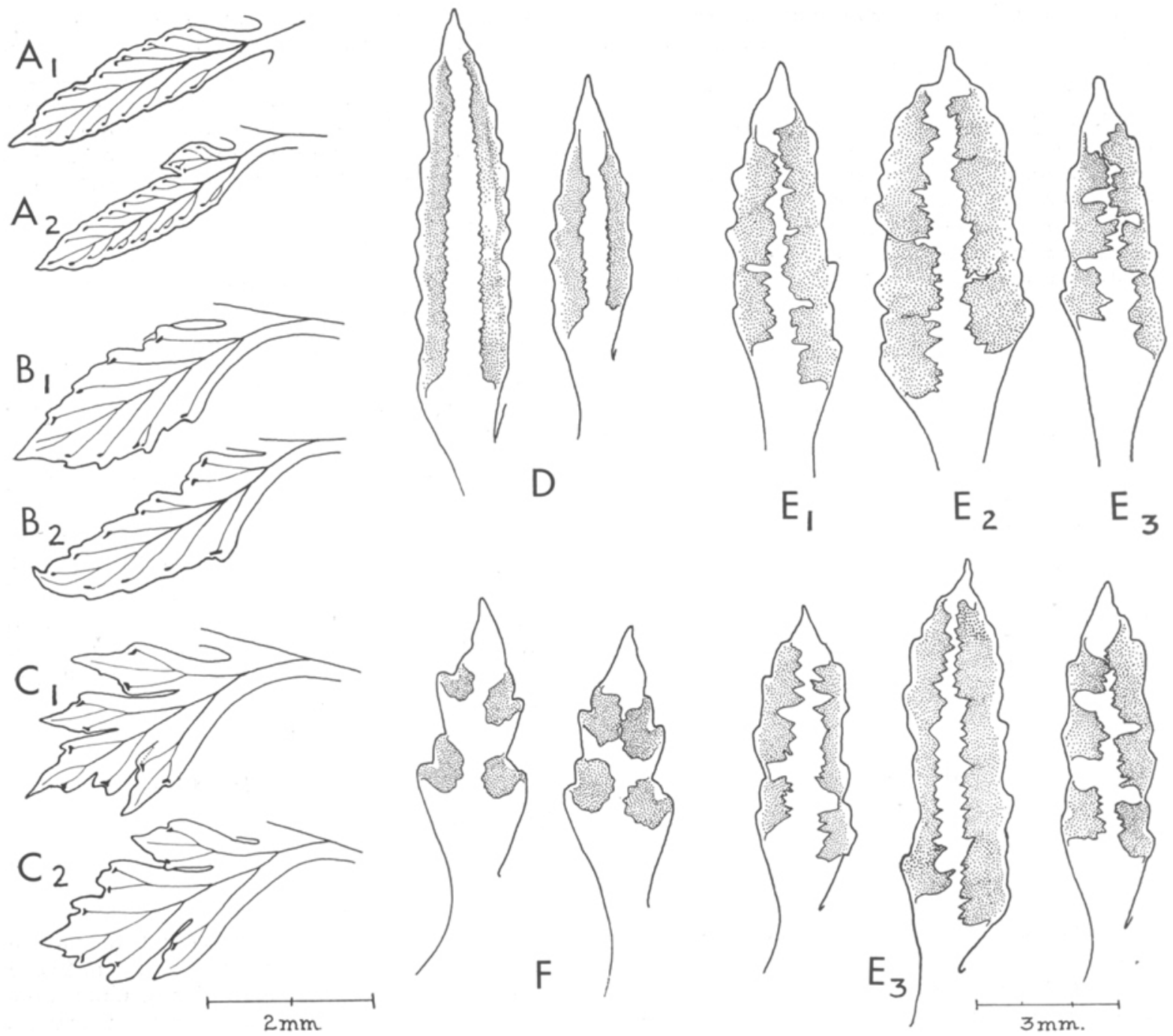

Fig. 2.-A-C. Venation patterns.-A. Cheilanthes siliquosa: A, Humboldt Co., Calif., Tracy 3354 (UC); $A_{2}$, Mariposa Co., Calif., Sharsmith 2176 (UC).-B. C. carlotta-halliae: $B_{1}$ and $B_{2}$, Marin Co., Calif., Wagner 4604 (MICH). -C. C. californica: $\mathrm{C}_{1}$, Amador Co., Calif., Mason 11075 (UC); Ce, Los Angeles Co., Calif., Clokey \& Templeton 1435 (UC).-D-F. Indusia (shaded).-D. C. siliquosa, Waldo, Oregon, Ownbey 1768 (MICH).-E. C. carlotta-halliae: $\mathrm{E}_{1}$, Upper Chorro Creek, Condit (UC) ; $\mathrm{E}_{2}$, Tiburon Hills, Eastwood (UC) ; $\mathrm{E}_{3}$, Marin Co., Calif., Wagner 4604 (MICH).-F. C. californica, Fall Brook, Calif., Marcus Jones (MICH).

comment concerning the latter species that "there is no other North American fern which it resembles even slightly." "4

Maxon was undecided, however, as to the final generic disposition of these plants and suggested

${ }^{4}$ A. A. Eaton (1897) described as a new species (Cheilanthes amoena) a plant from Fresno Co., California, which he believed to be intermediate between $C$. siliquosa and $C$. californica. The opinion of D. C. Eaton and of Carl Christensen that the plant was merely a small form of $C$. californica is confirmed by our examination of an isotype in the U. S. National Herbarium (no. 338192). The leaf dissection, pigmentation, and soriation are wholly typical of small individuals of $C$. californica. The strong but irregular coenosoral tendency characteristic of $C$. carlotta-halliae is entirely lacking. that Mildella might be their proper assignment. The treatment of the three species of ferns discussed in this paper is only one instance of a series of taxonomic problems at the generic-subgeneric level in the cheilanthoid fern assemblage. The situation points to the strong need of anatomical and cystological studies to unravel the complicated taxonomic picture in the cheilanthoid group, the species of which are reasonably clear-cut, but the genera confusing and poorly understood.

\section{SUMMARY}

Cheilanthes carlotta-halliae sp. nov, is a fern known only from three counties of California. It 
is unusual in being intermediate between $C$. siliquosa and $C$. californica in characters of leaf proportion, segment shape, costal pigmentation, and soriation. The sori of the new fern are remarkable for their irregularity in combining the coenosoral and discrete soral conditions, and they provide the best identification character. Cheilanthes carlottahalliae probably arose by hybridization of $C$. siliquosa and $C$. californica and this is indicated by its rarity and distribution in nature, the intermediacy of its morphology, the irregularity of the soriation. and the size of the spores that suggests polyploidy. Now that the species, $C$. siliquosa and $C$. californica, are connected by an intermediate species their assignment to the same genus is strongly supported. However, the precise determination of what genus this should be will have to depend on future broad comparative studies in the cheilanthoid ferns in general.

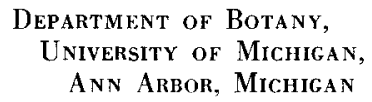

\section{I.ITERATURE CITED}

Copeland, E. B. 1947. Genera filicum, the genera of ferns. Chronica Botanica Co. Waltham, Mass.

DiEls, L. 1899. Loxsoma, Cyatheaceae, Polypodiaceae. In Engler und Prantl, Die natürlichen Pflanzenfamilien, Part I (4) : 112-336.

Eaton, A. A. 1897. A new Cheilanthes of the section Adiantopsis. Fern Bull. 5 (3) : 43-45.

Fernald, M. L. 1950. Gray's Manual of botany. 8th ed. American Book Co. New York.

Ноокеr, W. J. 1851. Species filicum, 2. London.

JEPSON, W. L. 1923. Manual of the flowering plants of California. Associated Students Store, Univ. California. Berkeley.
Maxon, W. R. 1918. Notes on American ferns-XII. The systematic position of Pellaea densa. Amer. Fern Journ. 8: 114-121.

W AGNer, W. H. 1954. Reticulate evolution in the Appalachian Aspleniums. Evolution 8: 103-108.

1956. A natural hybrid, Adiantum $\times$ tracyi C. C. Hall. Madroño 13 (6) : 195-205.

, and D. J. Hagenar. 1954. A natural hybrid of Polystichum lonchitis and $P$. acrostichoides from the Bruce Peninsula. Rhodora 56 (661): 1-6.

, AND . 1956. Observations on some bulbletproducing populations of the Cystopteris fragilis complex. Amer. Fern Journ. 46 (4) : 137-146.

\section{GIBBERELLIC ACID AND THE REVERSAL OF ADULT HEDERA TO A JUVENILE STATE ${ }^{1}$}

\section{William J. Robbins}

THE MARKED increase in growth in length evidenced by many kinds of plants after treatment with gibberellic acid suggested that this material be tested on the arborescent form of ivy (Hedera) to determine whether it might induce the arborescent form to revert to a juvenile state.

Ivy (Hedera sp.) grows from seed as a vine with palmately lobed leaves, aerial roots and a $2 / 2$ phyllotaxy. The vine produces no flowers. Eventually, under ill-defined conditions, the new growth of the vine, usually near the top, assumes a different morphology and physiology. The branches are orthotropic, no aerial roots are formed, the leaves are entire, the phyllotaxy is $2 / 5$ and this portion of the plant blooms. The vine portion is referred to as the juvenile form and the blooming branches as the adult. According to Tobler (1912) and to Frank and Renner (1956), it requires 10 years or more from seed to adult branches.

One of the most interesting features of the adult stage of the ivy is its stability when vegetatively propagated. A small piece of the adult portion of the plant rooted or used as a scion in a graft con-

\footnotetext{
${ }^{1}$ Received for publication June 18, 1957.

The assistance of Miss Christine Howson is gratefully acknowledged.
}

tinues to grow as a shrub or bush with the characters of the adult. Such s'irubby plants are known as Hedera sp. var. arborescens. The shrubby forms rarely revert spontaneously to the juvenile state. I have seen specimens of the arborescent ivy more than 50 years old, $2.5 \mathrm{~m}$. in height and $5 \mathrm{~m}$. in diameter which have never produced the vine or juvenile type of growth. I have observed also that old ivy vines which have become mainly or completely adult occasionally produce short shoots with juvenile leaves near the base of a trunk several inches in diameter. I found also at the Edinburgh Botanic Garden, an old arborescent ivy which had juvenile leaves on small shoots growing from the trunk near or below the ground. The seeds of the arborescent ivy produce vines, not shrubs. The adult form of the ivy is a stage in the normal ontogeny of the plant and is not a mutation nor a segregation from a chimera.

This phenomenon raises a number of questions. What causes the new growth on a 10-year-old ivy vine to assume the physiology and morphology of the adult? Why should the adult retain its characters through innumerable cell divisions even when vegetatively propagated and grown separately from the balance of the plant? Can the adult form 